\title{
LABILE COPPER AND ZINC FRACTIONS UNDER DIFFERENT SALINITY CONDITIONS IN A SHIPYARD AREA IN THE PATOS LAGOON ESTUARY, SOUTH OF BRAZIL
}

\author{
Luiza Dy Fonseca Costa*, Maria Regina de Oliveira Casartelli and Mônica Wallner-Kersanach \\ Instituto de Oceanografia ${ }^{*}$, Universidade Federal do Rio Grande, Avenida Itália, Km 08, Campus Carreiros, 96203-900 Rio Grande \\ - RS, Brasil
}

Recebido em 23/10/12; aceito em 9/5/13; publicado na web em 17/7/13

\begin{abstract}
Copper and zinc are common elements in paint residues and can be toxic to estuarine organisms. This study aims to determine the labile dissolved and labile particulate fractions (LPFs) of copper and zinc in the estuarine waters of a shipyard in southern Brazil under different salinity levels and in different seasons. The labile dissolved fraction was determined using the diffusive gradient in thin-film (DGT) technique. The variations in DGT-Cu (0.22-1.05 $\left.\mu \mathrm{g} \mathrm{L}^{-1}\right)$, DGT-Zn $\left(0.54-18.39 \mu \mathrm{g} \mathrm{L}^{-1}\right), \mathrm{LPF}-\mathrm{Cu}\left(1.22-3.77 \mu \mathrm{g} \mathrm{g} \mathrm{g}^{-1}\right)$, and LPF-Zn (4.29-19.12 $\left.\mathrm{g} \mathrm{g} \mathrm{g}^{-1}\right)$ concentration were related to changes in their physico-chemical parameters and as a result of boat maintenance activities.
\end{abstract}

Keywords: labile metals; DGT; suspended particulate matter.

\section{INTRODUCTION}

Shipyard activities can alter habitats, induce erosive processes and alterations on the coast line, and compromise the environment with a number of pollutants such as metals that can accumulate in coastal areas. ${ }^{1}$ Such activities are typically carried out in estuarine areas, where the chemical processes in the water are complex. The distribution of metals and their reactivity rates vary due to the residence time of the elements, and local hydrodynamics, mixture patterns, and transport processes of these elements in the environment. ${ }^{2}$

Several substances and materials that are used in shipyards contribute to environmental contamination, including dust, chemical products used in the maintenance of ships and in the conservation of wood, iron, oils, lubricants, solvents, water residues from ship hull washing, and antifouling paint particles. Most of these substances are discharged from the shipyards into the aquatic environment.

Metals, such as copper $(\mathrm{Cu})$ and zinc $(\mathrm{Zn})$, are present in high concentrations in antifouling paints ${ }^{3}$ that are applied to ship hulls to inhibit organism colonization and incrustation. ${ }^{4}$ Boats with engines can each release up to $2 \mathrm{~kg}$ of $\mathrm{Cu}$ per year from antifouling paints applied to them. ${ }^{5}$ Similar leaching can occur with $\mathrm{Zn}$ which, besides being an ingredient in antifouling paint, is also used in sacrificial anodes. ${ }^{6}$

In addition, after tributyltin (TBT) was banned from use in $2008,{ }^{7}$ there has been increased use of one the alternative biocides in antifouling paints, combination of $\mathrm{Cu}_{2} \mathrm{O}$ and $\mathrm{ZnO}$, as well $\mathrm{Zn}$ and Cu pyrithione. ${ }^{8}$

Although $\mathrm{Cu}$ and $\mathrm{Zn}$ are essential micronutrients needed for the growth of many aquatic organisms, they become toxic depending on their concentration and speciation in an aquatic environment. ${ }^{9}$

Considering the impact of trace metals on the environment and the lack of data about the effect of shipyard activities, the determination of trace metal concentrations in these areas has become imperative. In general, legislation only requires analysis of the total or dissolved concentration of metals, which is insufficient for evaluating their environmental impacts. Measuring labile fractions is the best alternative because these fractions can be incorporated into or altered in organism tissues. ${ }^{10,11}$ The biological profiles of organisms are related to the

*e-mail: luiza_dy@hotmail.com

\# Laboratório de Hidroquímica. levels of the readily bioavailable labile fractions of metals, existing as free metal ion $\left(\mathrm{M}^{2+}\right)$-hydrated ions or as metal complexes. ${ }^{11,12}$

In estuaries, natural hydrodynamics favors the remobilization and redistribution of bottom sediments. These processes are increased in dredging operation areas. In such cases, the analysis of suspended particulate matter (SPM) can be used to investigate changes related to the water and sediments, which may transport and redistribute large amounts of pollutants. ${ }^{13}$

The $\mathrm{pH}$ and salinity variations in water can also influence the degree to which labile metal fractions are released from estuarine sediments. Moreover, the chemical composition of SPM in an estuary is affected by physical and biogeochemical processes in transitional waters. ${ }^{13}$ Dissolved organic matter (DOM) in water may also regulate bioavailability of trace metals in water. ${ }^{14}$

The characteristics of estuaries contribute to the heterogeneous processes of dissolved phases of elements and SPM, which are fundamental to the geochemical cycles of metals. ${ }^{15}$ Montero et al. ${ }^{16}$ determined the labile fraction of metals $(\mathrm{Ni}, \mathrm{Cd}, \mathrm{Zn}$, and $\mathrm{Cu})$ in various estuaries, close to shipyard areas in Bay of Biscay (France). The diffusive gradient in thin-film (DGT) technique provided reliable data on the average labile metal concentration in these highly dynamic coastal and estuarine systems and shipyard areas. The study concluded that DGT made it possible to determine which estuaries were more susceptible to environmental impacts. Although there are numerous studies on the leaching behavior of antifouling paints in aquatic environments and their implications for the environment, ${ }^{3,4,16,17}$ these studies have been restricted to marinas and port areas.

Trace metal bioavailability can be estimated using the DGT technique, which has been successful in dynamic systems such as estuaries. ${ }^{6,18}$ The DGT device accumulates trace metals in situ to obtain time-averaged concentrations of the metals, ${ }^{19,20}$ thereby reducing the uncertainties that occur in conventional analytical methods for predicting bioavailability. ${ }^{11}$

Studies undertaken in the Patos Lagoon estuary in southern Brazil have measured the total trace metal concentrations in water and SPM in the estuary channel. ${ }^{21-23}$ These studies indicated low levels of metals in accordance with the national recommendations issued by CONAMA 357 (2005). ${ }^{24}$ However, the labile fraction of trace metals in the water column is not well known. 
The DGT technique differentiates metals based on kinetics, measuring only labile species (free metal cations, and inorganic and some small organic metal complexes). Free cations and metal complexes are transported by molecular diffusion through a cellulose nitrate filter $(0.45 \mu \mathrm{m}$ porosity) and polyacrylamide hydrogel (diffusive gel) due to a concentration gradient. The hydrogel regulates the entrance of the smallest metal complexes, which then dissociate and accumulate in a chelating resin gel, Chelex-100. The metallic ions retained in the resin are then eluted with acid solution and the concentrations of the available metals are analyzed..$^{20,25,26}$

A study using the DGT technique in the Patos Lagoon estuary showed an increase in labile metals in the water column during periods of high water salinity. ${ }^{12}$ However, no report on the seasonal behavior of labile metals is available.

The Santos Shipyard in Rio Grande city, Brazil, has been operating for more than two decades at the Patos Lagoon estuary. It is Rio Grande city's largest active shipyard for repairing boats ranging in size from 10 to $27 \mathrm{~m}$. The residue from antifouling paints used in the shipyard ends up in the estuarine water, and the development of the naval industry in this estuarine area will only increase the generation of residues. To minimize the environmental impact, studies of the estuarine area must be undertaken and waste-disposal programs implemented for managing the residues. As a first step, the labile concentrations of $\mathrm{Cu}$ and $\mathrm{Zn}$ in this area must be determined to assess the degree of water contamination under different salinity regimes, seasons, change in dominant wind direction, and alterations in the concentration of SPM.

The salinity in the Patos Lagoon estuary can remain stable for days at a time due to local wind patterns, which can also increase the amount of SPM in the water column. In that sense, the SPM fraction arising from the removal of sediments is an important parameter for evaluating metal contamination in coastal $\operatorname{areas}^{21,27}$ similar to the Patos Lagoon because those metals can be exchanged or incorporated by organisms. ${ }^{11}$

We recommend an extraction procedure using a diluted acid solution for leaching to obtain an "easily exchangeable" metal fraction in the SPM. This technique releases non-residual trace elements from the sediments and is closely associated with the summed concentrations released in three steps in a sequential extraction procedure..$^{21,28}$ This method seems to be the best approach to easily obtain labile metals in SPM, and are presumed to be appropriate for use with the DGT technique.

The aim of this study was to determine the labile dissolved fractions and labile particulate fractions ( $\mathrm{LPFs}$ ) of $\mathrm{Cu}$ and $\mathrm{Zn}$ in the water at the Santos Shipyard and to understand the behavior of these fractions under different salinity conditions in the same seasonal period.

\section{MATERIAL AND METHODS}

\section{Description of the study area}

The hydrodynamics of the Patos Lagoon estuary $\left(10,360 \mathrm{~km}^{2}\right)$ in southern Brazil is critically dependent on the northeast-southwest (NE-SW) wind system and fluvial discharge. The tide $(0.47 \mathrm{~m})$ is not as important a factor in the estuarine circulation. ${ }^{29} \mathrm{NE}$ winds prevail throughout the year, and they force the discharge of freshwater into the estuary, whereas SW winds are more influential in the autumn and winter and facilitate the entrance of sea water. ${ }^{29}$ The saline profiles of the estuary vary from homogeneous to well stratified, ${ }^{21}$ and salinity values oscillate between 0 and 34 .

These characteristics distinguish the Patos Lagoon from other estuarine systems in the world. ${ }^{27}$ Events such as El-Niño and La-Niña strongly affect the southern areas of Brazil, causing long periods of intense rain and droughts, respectively, and causing both freshwater and seawater to flow into and out of the estuary. ${ }^{30}$

Rio Grande Port, RS, Brazil, is located in the estuarine area and has been going through intense development following the installation of a 440,000 $\mathrm{m}^{2}$ dry dock for the construction and maintenance of oil platforms. It is located in the Superporto industrial area, where two more shipyards will be built. The present study focused only on the Santos shipyard $\left(32^{\circ} 08^{\prime} 210\right.$ “ S 52 $06^{\prime} 238$ “ W), located in this port area which has been operational in boat maintenance for the past 20 years (Figure 1). The Superporto industrial area does not generally discharge wastewater into the estuary. The urban and industrial wastewater that does outflow into the estuary does so about $9 \mathrm{~km}$ from the study area. ${ }^{31}$

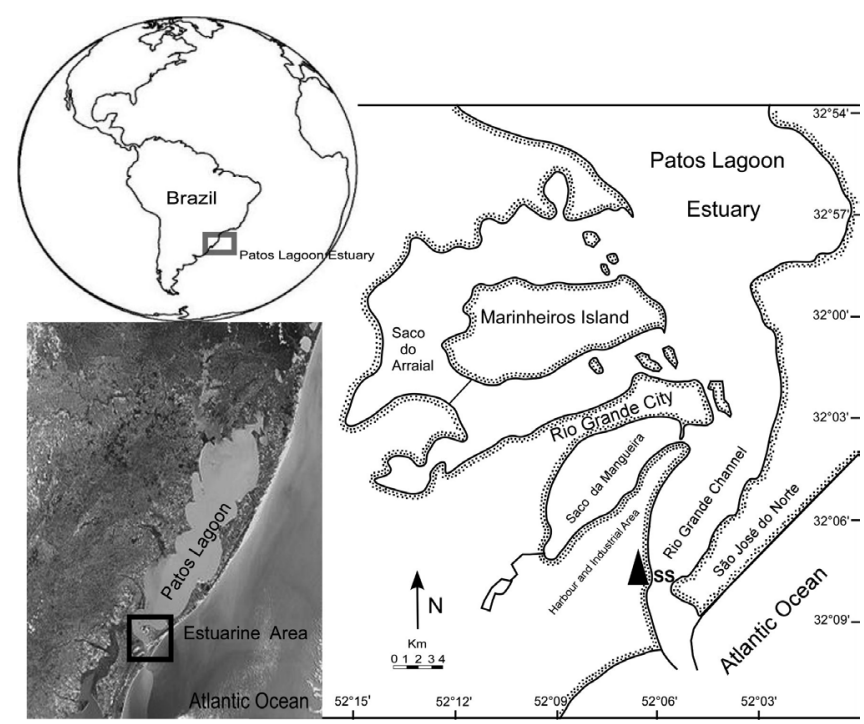

Figure 1. Sampling location area at the Santos Shipyard $(\mathbf{\Delta})$ in the Patos Lagoon estuary

\section{Gel preparation and assembly of DGT devices}

Plastic holders for the DGT devices were obtained from DGT Research Ltd., Lancaster (UK). The diffusive gel and the resin hydrogel were elaborated according to methods described by Zhang and Davison. ${ }^{20,32} \mathrm{~A}$ pre-gel solution was first prepared for both gels by combining acrylamide solution $(40 \%)$, agarose cross-linker (2\%) (DGT Research Ltd., Lancaster, UK) and ultrapure water. Polymerization was initiated using freshly prepared ammonium persulphate (10\%) and N,N,N'N'-Tetramethylethylenediamine (TEMED) (99\%), (Bio-Rad Laboratories, USA), mixed with the pre-gel solution. The resin gel was then prepared using the pre-gel solution in combination with an ion-exchange resin (Chelex-100, 200-400 mesh, sodium form) (Bio-Rad Laboratories, USA). Each gel solution $(10 \mathrm{~mL})$ was immediately cast between two acid-washed glass plates $(10 \mathrm{~cm} \times 10 \mathrm{~cm}$ and $10 \mathrm{~cm} \times 11 \mathrm{~cm})$, and separated by spacers of defined thickness for the diffusive gel $(0.5 \mathrm{~mm})$ and the resin gel Chelex-100 (0.25 mm). To keep the gel solution uniform and without bubbles and to facilitate pipetting, both the solutions and the glass plates were kept on ice to avoid polymerization.

The assembly was maintained at approximately 42 to $46{ }^{\circ} \mathrm{C}$ for at least $1 \mathrm{~h}$ until the gel was completely set. ${ }^{26}$ The gels were immediately hydrated with ultrapure water for at least $24 \mathrm{~h}$, and the ultrapure water was replaced several times before use. After hydration, the measured thickness of the diffusive gel was $0.80 \pm 0.01 \mathrm{~mm}$ and that of the resin gel was $0.44 \pm 0.01 \mathrm{~mm}$. A digital caliper was used to measure the thickness of both gel sheets for each new lot of 
elaborated gels. Gels sheets were stored under refrigeration $\left(4{ }^{\circ} \mathrm{C}\right)$ in solutions of $0.01 \mathrm{~mol} \mathrm{~L}^{-1}$ sodium nitrate (Merck, Germany) before being cut into $25 \mathrm{~mm}$ discs with an acrylic cutter. The thickness of some gel disks were measured once more and discarded afterwards. All procedures were done on a laminar flow bench using disposable and powder-free gloves.

The DGT plastic holders were placed in the open position on a laminar flow bench. Initially, each of the Chelex-100 resin gels was placed in a $25 \mathrm{~mm}$ base, followed by the diffusive gel and a cellulose nitrate filter $(0.45 \mu \mathrm{m}$ porosity $)$. The filters were washed in $0.1 \mathrm{~mol}$ $\mathrm{L}^{-1}$ Suprapur ${ }^{\circledR}$ (Merck, Germany) nitric acid and thoroughly rinsed with ultrapure water. The resin gel was arranged to ensure that the side with the settled resin was placed against the diffusive gel.

To test the seal of the DGT devices, a few drops of ultrapure water were added to the display window. The DGT devices were considered useable if there was no leakage. Each DGT device was individually stored in a clean zip-lock plastic bag containing a few drops of sodium nitrate $\left(0.01 \mathrm{~mol} \mathrm{~L}^{-1}\right)$ and refrigerated at $4{ }^{\circ} \mathrm{C}$ until the exact moment of use in the laboratory or in situ.

After preparation, the DGT devices were tested in the laboratory and $\mathrm{Cd}$ concentrations were measured according to the DGT research protocol. $^{26,32}$ Two experimental solutions with $10 \mathrm{ppb}$ of Cd were prepared and triplicate DGT units were immersed into each for $4 \mathrm{~h}$. The mean $\mathrm{Cd}$ concentrations obtained in each experimental solution were 10.47 and $9.84 \mu \mathrm{g} \mathrm{L}^{-1}$. The average $\mathrm{Cd}$ recovery of the triplicate DGT resin for each solution was 90 and $103 \%$. The results obtained in the duplicate blank (controls) solution were $0.05 \mu \mathrm{g} \mathrm{\textrm {L } ^ { - 1 }}$.

\section{DGT deployment}

The DGT devices were deployed in winter (July 2010), spring (October 2010) and summer (January 2011) at the Santos Shipyard in the same location each time (Figure 1).

The La Niña effect, which began in the spring of 2010 and ended in the autumn of 2011, was characterized by drought and reduced discharge of freshwater through the Patos Lagoon estuary. DGT deployment occurred in two different constant salinity conditions during each seasonal period with an interval of 7 days between each one. The seasonal deployments were initially planned to be conducted during low- and high-salinity water conditions in the estuary. However, the climate conditions in addition to the La Niña effect did not make deployment possible under both salinity conditions.

The total DGT deployment time was two days (48 h) for each hydrological condition. In total, 6 deployments were carried out, two in each seasonal period. Following a conceptual model of the distribution and behavior of dissolved metals $v s$. salinity in the Patos Lagoon estuary, the range of salinity was classified as low (0-6), intermediate (6-25) or high (above 25). ${ }^{22}$

In each deployment period, four devices were attached to a rope fixed on a pier at $0.5 \mathrm{~m}$ depth about $10 \mathrm{~m}$ from the margin area of the estuary. Water samples were collected daily at the depth of the DGT devices using a Niskin bottle to determine $\mathrm{pH}$ ( $\mathrm{pH}$ meter by Toledo, Model DM), temperature and salinity (conductivity with WTW brand, Model 315i). Water samples were also taken to measure the concentration of SPM, the labile particulate fractions (LPFs) of metals $(\mathrm{Cu}$ and $\mathrm{Zn})$, dissolved organic carbon (DOC), and particulate organic carbon (POC).

After $48 \mathrm{~h}$, the DGT devices were removed from the water, washed with ultrapure water, placed individually in plastic bags, and transported under refrigeration to the laboratory. In each period, two DGT devices were randomly selected as control devices, and were not deployed in the water column. Instead, they were transported to the field in clean plastic bags and subsequently returned to the laboratory.
The DGT control averages $(n=12)$ of the method detection limits $(3 \sigma)$ in July and October of 2010 and in January of 2011 were 0.041 $\mu \mathrm{g} \mathrm{L} \mathrm{L}^{-1}$ for $\mathrm{Cu}$ and $0.12 \mu \mathrm{g} \mathrm{\textrm {L } ^ { - 1 }}$ for $\mathrm{Zn}$.

\section{Laboratory procedure}

Trace metals were eluted from the resin gels (Chelex-100) (gel volume $=0.15 \mathrm{~mL}$ ) of each DGT device with $1.0 \mathrm{~mL}$ of $1 \mathrm{~mol} \mathrm{~L}^{-1}$ Suprapur $^{\circledR}$ (Merck, Germany) nitric acid and kept under refrigeration $\left(4{ }^{\circ} \mathrm{C}\right)$ until analysis. ${ }^{20}$

Duplicate water samples $(500 \mathrm{~mL})$ were filtered through a 0.45 $\mu \mathrm{m}$ filter membrane of cellulose nitrate (Sartorius, Germany) that had been previously washed in $0.14 \mathrm{~mol} \mathrm{~L}^{-1}$ Suprapur $^{\circledR}$ (Merck, Germany) nitric acid solution and rinsed with ultrapure water for the subsequent simultaneous analysis of SPM and the LPFs ( $\mathrm{Cu}$ and $\mathrm{Zn}$ ). After water filtration, the filters with the particulate material were washed with ultrapure water to reduce chlorides and dried in an oven at $60{ }^{\circ} \mathrm{C} .{ }^{33,34}$

The filters for the analysis of LPF fractions were leached with 0.1 mol L ${ }^{-1}$ Suprapur $^{\circledR}$ (Merck, Germany) hydrochloric acid for $24 \mathrm{~h}$ under continuous shaking at room temperature. The leaching solution was left to rest for $5 \mathrm{~h}$ to allow for complete decantation of the solids and was subsequently filtered with a Whatman no. 44 filter. The resulting extracts were transferred to $25 \mathrm{ml}$ volumetric flasks and filled with 0.1 mol L $^{-1}$ Suprapur $^{\circledR}$ (Merck, Germany) hydrochloric acid solution. ${ }^{25}$

The analysis of DOC was performed according to Spyres et al. ${ }^{35}$ The samples were acidified with hydrochloric acid, which converted all of the inorganic carbon species into carbon dioxide, and then analyzed using a Total Organic Carbon (TOC) Elemental Analyzer (Shimatzu Brand, Model TOC V - Series).

The analysis of POC followed the method described by Ehrhardt and Koeve. ${ }^{36}$ Prior to analysis, the samples were fumed with concentrated hydrochloric acid (Merck, Germany) for $24 \mathrm{~h}$ to remove the carbonate fraction and then analyzed using a CHNS/O Elemental Analyzer (Series 2400, Perkin Elmer). The volume of the water filtration was considered during the analysis and the results of POC were expressed in $\mathrm{mg} \mathrm{L}^{-1}$ as a relative concentration.

All of the materials used for the analysis of trace metals and TOC were washed previously with a $20 \%$ solution $(v / v)$ of nitric acid and hydrochloric acid (Merck, Germany).

The concentrations of $\mathrm{Cu}$ and $\mathrm{Zn}$ in the eluted solution of each Chelex-100 resin gel were analyzed using graphite furnace atomic absorption spectrometry (GFAAS) (Analyst 600, Perkin Elmer) equipped with a transversely heated graphite atomizer $\left(\mathrm{THGA}^{\mathrm{TM}}\right)$ and a longitudinal Zeeman-effect background correction. A hollow cathode lamp (HCL) was used for $\mathrm{Cu}(324.8 \mathrm{~nm})$ and $\mathrm{Zn}(213.9$ $\mathrm{nm})$. The $\mathrm{Cu}$ pyrolysis temperature was $1200{ }^{\circ} \mathrm{C}$ and the atomization temperature was $2000{ }^{\circ} \mathrm{C}$, while the $\mathrm{Zn}$ pyrolysis temperature was $500{ }^{\circ} \mathrm{C}$ and its atomization temperature was $1900{ }^{\circ} \mathrm{C}$. Argon was used as the purge gas.

The DGT concentration calculations followed those described by Zhang and Davison. ${ }^{20}$ The elution factor for each metal was 0.8 . The water temperature of the DGT retrieval time was considered to verify the diffusion coefficient of the DGT Research Ltda protocol. ${ }^{26}$ The quality control of the DGT analysis for the GFAAS used river water from the National Research Council of Canada, a SLRS-4 certified reference material. The mean percentage recovery of the certified values was $96 \%$ for $\mathrm{Cu}$ and $102 \%$ for $\mathrm{Zn}$. The instrumental detection limits $(3 \sigma)$ were 0.03 and $0.06 \mu \mathrm{g} \mathrm{L}^{-1}$ for $\mathrm{Cu}$ and $\mathrm{Zn}$, respectively.

The accuracy of the LPF method was determined by spiking three different sample aliquots with three known $\mathrm{Cu}$ and $\mathrm{Zn}$ concentrations $\left(25,40\right.$, and $\left.60 \mu \mathrm{g} \mathrm{L}^{-1}\right) . \mathrm{Cu}(327.4 \mathrm{~nm})$ and $\mathrm{Zn}(213.9 \mathrm{~nm})$ were determined by inductively coupled plasma optical emission spectrometry 
(ICP-OES) (Perkin Elmer, Model Optima 2100 DV) using axial vision. The mean percentage recoveries of the spikes were $97.72 \%$ (25 $\left.\mu \mathrm{g} \mathrm{L}^{-1}\right), 104.27 \%\left(40 \mu \mathrm{g} \mathrm{L}^{-1}\right)$, and $103 \%\left(60 \mu \mathrm{g} \mathrm{L}^{-1}\right)$ for the $\mathrm{Cu}$ concentrations. The $\mathrm{Zn}$ concentrations indicated a mean percentage recovery of $106.5 \%\left(25 \mu \mathrm{g} \mathrm{L}^{-1}\right), 100.6 \%$ (40 $\left.\mu \mathrm{g} \mathrm{L}^{-1}\right)$, and $106.5 \%$ (60 $\left.\mu \mathrm{g} \mathrm{L}^{-1}\right)$. The recovery variations were between $\pm 10 \%$ for both metals as recommended by Harris. ${ }^{37}$ The method detection limits (3) were 0.05 and $0.13 \mu \mathrm{g} \mathrm{g}^{-1}$ for $\mathrm{Cu}$ and $\mathrm{Zn}$, respectively.

For the statistical analysis, all of data were tested for normality and homogeneity. The results of the DGT-Cu and DGT-Zn were transformed into $\log (x+1)$. Analysis of variance (ANOVA) was used to identify significant differences between the DGT-Cu and DGT-Zn in the different seasons at a 5\% significance level ${ }^{38}$ After the difference was established, a post hoc Tukey test was performed. The LPF-Cu and LPF-Zn data met the assumptions, and no transformation was necessary.

To verify the relations between DGT-Cu and DGT-Zn and between $\mathrm{LPF}-\mathrm{Cu}$ and $\mathrm{LPF}-\mathrm{Zn}$ regarding their different physicochemical parameters analyzed in water based on the $48 \mathrm{~h}$ deployment of DGT devices, a Pearson correlation test was applied to the data collected in different seasons, using a 5\% significance level. Climate information (rain, wind direction, and tide) used for the interpretation of results was obtained from the Praticagem de Rio Grande. ${ }^{39}$

\section{RESULTS AND DISCUSSION}

\section{Physicochemical parameters}

The physicochemical parameters for the periods in which the DGT devices were deployed at the Santos Shipyard are shown in Table 1. In winter, the DGT devices were deployed in high- and low-salinity periods. During the second deployment, the water salinity and $\mathrm{pH}$ decreased because of the northeast winds causing freshwater discharge into the estuary.

In spring, the first DGT deployment period indicated a dominance of freshwater in the estuary followed by a decrease in $\mathrm{pH}$ (6.3) and by the highest value of DOC $\left(5.4 \mathrm{mg} \mathrm{L}^{-1}\right)$ and, then, by an increase in POC $\left(2.7 \mathrm{mg} \mathrm{L}^{-1}\right)$. Freshwater normally promotes the increase of organic-rich fluvial material in the estuary, i.e., DOC, which decreases with the increase in water salinity. ${ }^{40}$ The second period showed a water salinity of 12.4 , considered to be intermediate. The temperature remained in the same range, and the $\mathrm{pH}$ increased to 7.9 because of the buffer effect of seawater in the estuary. The highest SPM concentrations were verified in the second period $\left(103.2 \mathrm{mg} \mathrm{L}^{-1}\right)$, when the salinity was intermediate due to the SW winds facilitating the entry of seawater into the estuary. During this period, a decrease in the DOC ( $\left.4.9 \mathrm{mg} \mathrm{L}^{-1}\right)$ concentrations and an increase in the POC (and $8.7 \mathrm{mg} \mathrm{L}^{-1}$ ) in the estuarine water were observed, in comparison with the winter period, indicating the presence of phytoplankton blooms. Phytoplankton blooms are common in spring and summer time and can affect the metal availability and toxicity depending on the chemical speciation of metal-DOC. This interaction plays a fundamental role in the transport, discharge, and lability of the metals. ${ }^{41}$

The salinity in summer was high in the first DGT deployment and intermediate in the second one. Decreases in the wind speed and the low precipitation of summer frequently caused an increase in the salinity of the estuary. The temperature was high in both summer periods, while the $\mathrm{pH}$ remained nearly the same. The lowest SPM concentration of $42 \mathrm{mg} \mathrm{L}^{-1}$ was observed during the second period of the DGT device deployment during two days the estuary was at an intermediate salinity state, due to the presence of NNE winds, which slow down the entrance of seawater into the estuary and the sediment remobilization to the water column.
One of the characteristics of the estuarine area at the Santos Shipyard is its strong hydrodynamics that contribute to the remobilization of bottom sediments. The SPM is continuously modified through aggregation and re-suspension processes, ${ }^{42}$ usually linked to the entrance of seawater into the estuary.

The Santos Shipyard receives boats to be repaired throughout the year. However, the busiest period is usually from October to May, so this is when the highest amount of residues of antifouling paints and fragments are released to the water. In addition, a direct impact of antifouling paint occurs when boats are launched into the water. Boat launching occurs in the first $72 \mathrm{~h}$ after the application of antifouling paint to the boat hull in order to increase the efficient release of its antifouling coating into the water. ${ }^{43}$ Finally, launching and removing boats from the water typically also causes the remobilization of the bottom sediment in the area, which increases levels of SPM and may also liberate labile fraction of metals into the water column.

\section{DGT-labile metal concentrations}

The DGT-Cu and DGT-Zn labile concentrations in the water changed according to the estuarine hydrodynamics (Figure 2). The DGT-Cu showed a significant $(\mathrm{p}<0.05)$ decrease in the winter when water salinity was low compared to when salinity was high in the summer. The DGT-Zn in the winter when water salinity was high was also significantly $(\mathrm{p}<0.05)$ higher than when salinity was intermediate during the summer.

In the spring, the combined influence of the La Niña effect and greater amounts of freshwater in the estuary caused high variability
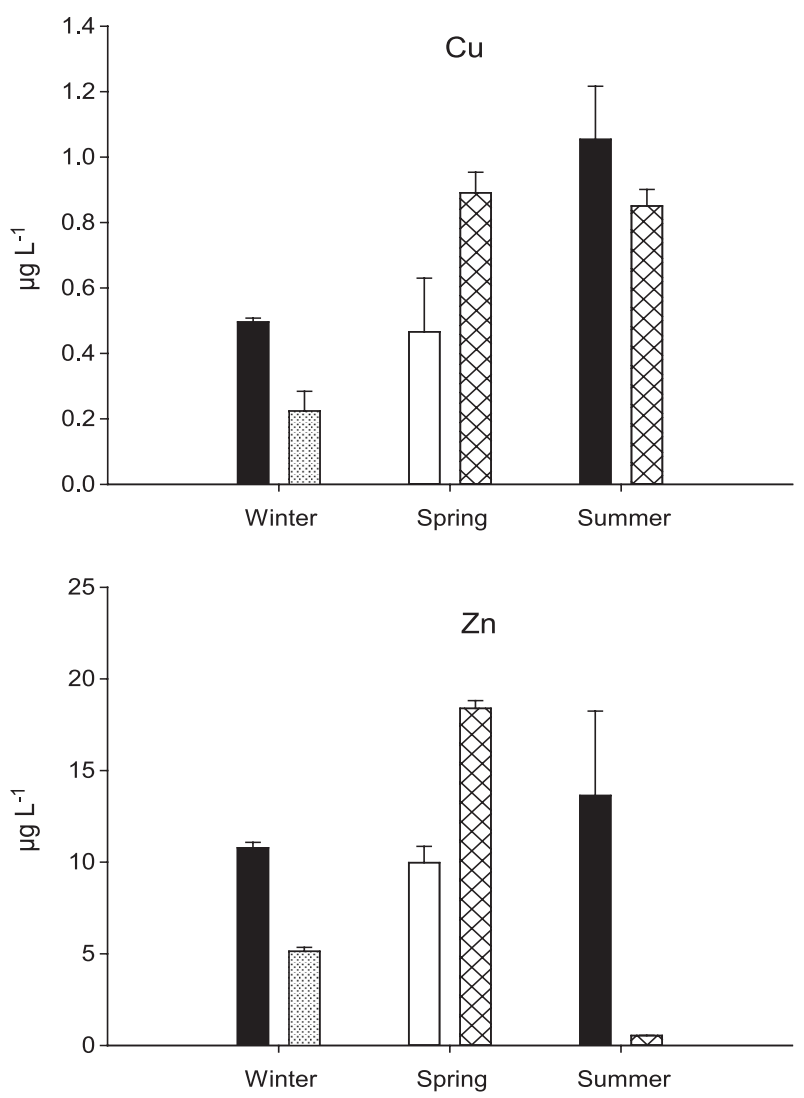

Figure 2. DGT-labile concentrations ( $\left.\mu g L^{-1}\right)$ of copper and zinc in highsalinity (black bar), intermediate-salinity (hatched bar), and low-salinity (dotted bar) water and in freshwater (white bar) after $48 \mathrm{~h}$ of DGT deployment at the Santos Shipyard. The DGT data were compiled from two deployments in each seasonal period; mean $\pm S E, n=2-3$ 
in the DGT-Cu and DGT-Zn in the water. The DGT-Cu and DGT-Zn vary significantly $(\mathrm{p}<0.05)$ in freshwater and intermediate-salinity water. The DGT-Zn was the highest $\left(18.38 \mu \mathrm{g} \mathrm{L} \mathrm{L}^{-1}\right)$ in intermediatesalinity water, when the SPM and POC concentration in water was also high. The NE wind that blows on the margin of the shipyard area favored the remobilization of sediments in nearby shallow areas increasing the SPM in the estuarine water. This suggests the liberation of labile $\mathrm{Zn}$, since the availability of metals in sediment is affected by changes in $\mathrm{pH}$ and salinity. ${ }^{13}$ During this period, the winds were more persistent and varied from $\mathrm{NE}$ to $\mathrm{N}$.

In the summer, the mean DGT-Cu concentration of $1.05 \mu \mathrm{g} \mathrm{L}^{-1}$ in high-salinity water was comparable to the intermediate-salinity of the summer and spring periods. The mean DGT-Zn concentration was also high in the high-salinity environment but showed high mean variability as well. The expressive decline in the DGT-Zn concentrations in the intermediate-salinity was related not only to the salinity decrease but also to the $41 \mathrm{mg} \mathrm{L}^{-1}$ SPM decline because $\mathrm{Zn}$ has more affinity with the particulate phase in water than does $\mathrm{Cu}^{44,45}$

The largest variability in DGT-Cu and DGT-Zn (represented by the \pm standard error) was observed in spring and summer. This finding suggests that in addition to the environmental factors the intense maintenance activity and high number of boats moored in the shipyard, for both periods of the study, might have contributed to this variation.

The concentrations of DGT-Cu showed a moderate correlation with the $\mathrm{pH}(\mathrm{r}=0.58)$ and salinity $(\mathrm{r}=0.65)$, indicating that seawater entrance into the estuary favored $\mathrm{Cu}$ bioavailability in the water column. The absence of a significant correlation between the SPM and DGT-Cu concentrations found in the estuary is in agreement with findings by Munksgaard and Parry, ${ }^{46}$ who studied labile metals in turbid coastal seawater.

The DGT-Zn concentrations were found to be dependent on the LPF-Zn $(r=0.69, \mathrm{p}<0.05)$, POC $(\mathrm{r}=0.66, \mathrm{p}<0.05)$ and the SPM $(\mathrm{r}=0.99, \mathrm{p}<0.05)$ concentrations in water. The importance of salinity and $\mathrm{pH}(\mathrm{r}=0.84, \mathrm{p}<0.05)$, as well as the load of SPM levels, to the bioavailability of metals in water was previously determined in a preliminary study carried out in the same estuary. ${ }^{12}$

Because of recent increases in the amount of $\mathrm{Cu}$ used in antifouling paints, the concentration of this element is high in the waters around marinas and port areas. ${ }^{47}$ In addition, Warnken et $a l .{ }^{6}$ and Dunn et al. ${ }^{19}$ demonstrated a direct relationship between the DGT-Cu and DGT-Zn concentrations and the number of recreational boats in marinas. Both $\mathrm{Cu}$ and $\mathrm{Zn}$ found in paints produce a synergic effect on organisms. $\mathrm{Zn}$ is also used in sacrifice anodes, but its release from boats has not been studied yet.

Turner et al. ${ }^{17}$ studied antifouling paint fragments and verified that although $\mathrm{Cu}$ has been found at higher concentrations in water, these high concentrations do not reflect the total concentration in the original formulations of antifouling paints because the fragments can undergo seawater leaching and because the release of $\mathrm{Cu}$ is gradual in water.

A marina in San Diego Bay was evaluated regarding its $\mathrm{Cu}$ concentration. Over a two month period, boat occupation and movement increased the dissolved and total concentrations of $\mathrm{Cu}$. Before the installation of that marina, the $\mathrm{Cu}$ levels had been within the limits established for Criteria of Water Quality in California, according to authors Biggs and D'Anna. ${ }^{48}$

Studies carried out in shipyard areas are very scarce. Recent study showed high values of labile $\mathrm{Cu}$ and $\mathrm{Zn}$ in shipyard areas (including Santos shipyard) in the southern region of the Patos Lagoon when compared with marina Rio Grande Yacht Club and an area having no anthropogenic contributions. In the latter, a mean value of $0.13 \mu \mathrm{g}$ $\mathrm{L}^{-1}$ of $\mathrm{Cu}$ and $2.99 \mu \mathrm{g} \mathrm{L}^{-1}$ of $\mathrm{Zn}^{49}$ was measured. When the data from this study are compared with the maximum concentrations reported by Dunn et al. $\left(0.28 \mu \mathrm{g} \mathrm{L}^{-1} \text { of } \mathrm{Cu} \text { and } 0.83 \mu \mathrm{g} \mathrm{L} \mathrm{L}^{-1} \text { of } \mathrm{Zn}\right)^{19}$ and Warken et al. $\left(0.45 \mu \mathrm{g} \mathrm{L}^{-1}\right.$ of $\mathrm{Cu}$ and $38 \mu \mathrm{g} \mathrm{L}^{-1}$ of $\mathrm{Zn}$; and a control location: $0.29 \mu \mathrm{g} \mathrm{L}^{-1}$ of $\mathrm{Cu}$ and $5.5 \mu \mathrm{g} \mathrm{L}^{-1}$ of $\left.\mathrm{Zn}\right)^{6}$ in estuarine waters, the mean DGT-Cu and DGT-Zn concentrations were found to be significantly higher in the Santos Shipyard. On the other hand, Montero et al. ${ }^{16}$ studied a freshwater area near shipyards and obtained lower DGT-Cu (0.18-0.35 $\left.\mu \mathrm{g} \mathrm{L}^{-1}\right)$ but higher DGT-Zn (5.0-22.5 $\left.\mu \mathrm{g} \mathrm{L}^{-1}\right)$ values than those observed in this study due to mining activities in the area of that study.

The results of this study show that shipyard areas may generate higher DGT-Cu and DGT-Zn concentrations in the estuarine water of the Patos Lagoon, as compared with the data of other studies. These elements are also affected by the physicochemical estuarine conditions and by contributions from the maintenance of boats, the leaching of antifouling paints and the remobilization of contaminated sediments.

\section{Labile particulate concentrations (LPF) of $\mathrm{Cu}$ and $\mathrm{Zn}$}

The salinity changes commonly observed in estuaries are responsible for the variation in the dissolved and labile particulate fractions of metals in water. ${ }^{2}$ However, the variation in other parameters, such as $\mathrm{pH}$ and SPM, caused by the entrance of seawater into the estuary, plays an important role in the regulation of metal availability in the water column. Estuaries can be efficient filters for SPM because of the interaction of particulate/solute, flocculation, coagulation and particle sedimentation processes linked to the trace metals. ${ }^{50}$

Some interactions were observed for the LPF of metals at the Santos Shipyard. The mean LPF-Cu and LPF-Zn concentrations in Figure 3 are the result of duplicate analyses.

The $\mathrm{LPF}-\mathrm{Cu}$ values varied from 1.22 to $3.77 \mu \mathrm{g} \mathrm{g}^{-1}$ and were comparable in the same seasonal period, as observed in winter and summer (Figure 3). The lowest concentrations in the summer were related to the dominance of seawater in the estuary and decrease in the SPM concentrations.

In spring, the LPF-Cu levels increased in intermediate-salinity conditions as compared with the concentrations when freshwater dominated the estuary. Similar changes were observed in the LPF-Zn levels in the spring, indicating a marked increase in this element, as well as in the SPM and POC concentrations, in intermediate-salinity conditions. In the winter and summer, the LPF-Zn concentration varied more widely, possibly because of the SPM variations in the estuarine water (Table 1).

The LPF-Zn concentrations varied from 4.29 to $19.12 \mu \mathrm{g} \mathrm{g}^{-1}$. The decrease in the LPF-Zn levels in the intermediate-salinity water in the summer was caused by the decrease in SPM, which caused a steep decrease in the DGT-Zn concentration as well (Figure 2). The relationship between LPF-Zn and SPM was further confirmed by the correlation between SPM $(r=0.69, p<0.05)$, POC $(r=0.71, p<$ $0.05)$ and DGT-Zn $(r=0.69, \mathrm{p}<0.05)$. This result shows that part of the labile $\mathrm{Zn}$ concentrations in water originates from the suspended particulate fractions, both organic and inorganic. Further, a strong correlation was observed between the LPF-Cu and LPF-Zn concentrations $(r=0.82, p<0.05)$, which suggests that both metals may have come from the same source, i.e., anti-fouling paint residues deposited in the sediment and leached by seawater.

The sediment remobilization certainly contributed to an increase of the $\mathrm{Cu}$ and $\mathrm{Zn}$ available in the area near the estuary edge of the shipyards because of the sediment having been contaminated. ${ }^{50}$ The study area is a lagoon in which the salinity is governed by the wind direction and intensity. Thus, sediments can be remobilized and then promote the availability of metals affected by changes in $\mathrm{pH}$ and salinity. ${ }^{13}$ 
Table 1. Physicochemical parameters of the water based on $48 \mathrm{~h}$ of DGT device deployment in different seasonal periods at the Santos Shipyard

\begin{tabular}{|c|c|c|c|c|c|c|}
\hline Period & Salinity & Temperature $\left(\mathrm{T}^{\circ} \mathrm{C}\right)$ & $\mathrm{pH}$ & $\mathrm{SPM}\left(\mathrm{mg} \mathrm{L}^{-1}\right)$ & $\mathrm{DOC}\left(\mathrm{mg} \mathrm{L}^{-1}\right)$ & POC $\left(\mathrm{mg} \mathrm{L}^{-1}\right)$ \\
\hline Winter -1 & 28.9 & 13.0 & 8.2 & 81.6 & 3.1 & 1.0 \\
\hline Winter -2 & 1.2 & 11.9 & 7.0 & 66.8 & 2.7 & 1.8 \\
\hline Spring-1 & 0.0 & 21 & 6.3 & 78.0 & 5.4 & 2.7 \\
\hline Spring-2 & 12.4 & 20.1 & 7.9 & 103.2 & 4.9 & 8.7 \\
\hline Summer-1 & 32.0 & 24.5 & 7.8 & 90.0 & 2.3 & 0.9 \\
\hline Summer-2 & 23.7 & 25.9 & 8.1 & 42.0 & 2.6 & 0.9 \\
\hline
\end{tabular}
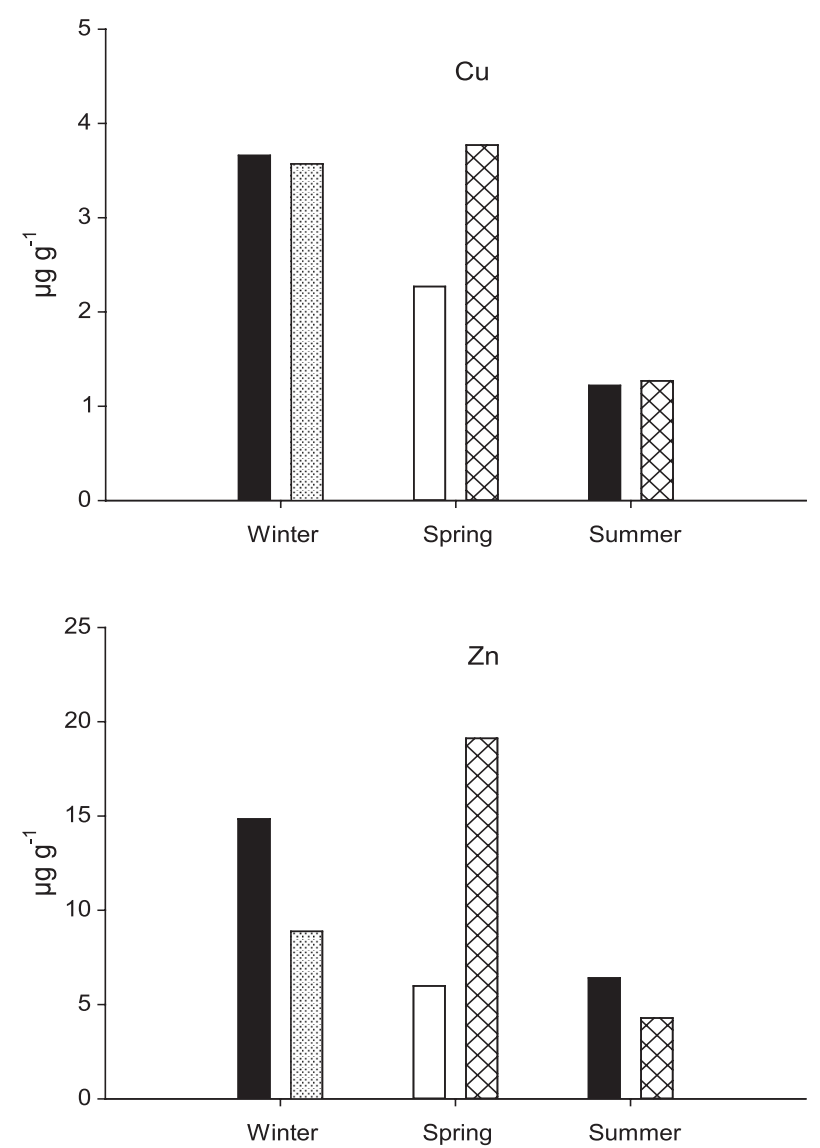

Figure 3. Particulate labile concentrations $\left(\mu g \mathrm{~g}^{-1}\right)$ of copper and zinc in high-salinity (black bar), intermediate-salinity (hatched bar), and low-salinity (dotted bar) water and in freshwater (white bar) after 48 h of DGT deployment at the Santos Shipyard. The data were compiled from two deployments in each seasonal period; mean data $(n=2)$

The interactions between the labile dissolved fraction and the labile particulate fraction of $\mathrm{Cu}$ and $\mathrm{Zn}$ can occur through adsorption, cation exchange reactions or complexation, when seawater flows into the estuary. Among these reactions, complexation is the most significant because it affects the geochemical metallic ions, modifying element solubility, load and potential redox. These changes affect the availability, transport and migration of metals in the aquatic ecosystems.

\section{CONCLUSION}

Navigation and the activities supporting navigation in marinas, ports and shipyard areas are responsible for the input of trace metals, such as $\mathrm{Cu}$ and $\mathrm{Zn}$, in the aquatic environment. This study measured the levels of $\mathrm{Cu}$ and $\mathrm{Zn}$ labile concentrations in the water of a shipyard area in the Patos Lagoon estuary.
The DGT-Cu concentration was dependent on changes in the $\mathrm{pH}$ and salinity of the water. The DGT-labile and labile particulate concentrations of $\mathrm{Zn}$ were found to be associated with both the SPM and POC fractions. These fractions were also found to be correlated with each other. This result suggests that both fractions originate from the same anthropogenic source: antifouling paint residues.

Shipyard activities increase during spring and continue until autumn, consequently, boat maintenance contributes to the trace metal input to the estuarine water. This factor must be considered because it leads to high variability in the results of the DGT device replicates. The change of the labile $\mathrm{Cu}$ and $\mathrm{Zn}$ concentrations in water are primarily affected by the physicochemical estuarine conditions and this should also be taken into consideration.

The mean concentrations of DGT-Cu and DGT-Zn found at the Santos shipyard were higher than those found in other marinas having large numbers of boats. However, the water hydrodynamics in the shipyard area we studied experiences greater hydrological change and dispersion of pollutants due to the shipyard's location in the narrow part of the estuary.

Taking action to minimize the discharge of residues in shipyard areas will be of great value, since the input of $\mathrm{Cu}$ and $\mathrm{Zn}$ from these activities is more localized and causes greater environmental impact. The same holds true for marina waters, where these metals are released from antifouling paints and are more easily dispersed in the water.

Labile $\mathrm{Cu}$ and $\mathrm{Zn}$ data from the present study may serve as a basis for the development of risk assessment strategies. Further studies of marine organisms and continued utilization of the DGT technique for in situ and toxicological tests in laboratories may aid in the understanding of $\mathrm{Cu}$ and $\mathrm{Zn}$ bioavailability in shipyard areas.

\section{ACKNOWLEGMENTS}

The National Council for Scientific and Technological Development (CNPq- Project No. 4824851/2009) and the Coordination for the Improvement of Higher Level Personnel (CAPES) for L. D. F. Costa's research grants.

\section{REFERENCES}

1. Neser, G.; Kontas, A.; Ünsalan, D.; Uluturban, E.; Altay, O.; Darilmaz, E.; Kucuksezgin, F.; Tekogul, N.; Yercan, F.; Mar. Pollut. Bull. 2012, 64, 882.

2. Hatje, V.; Apte, S. C.; Hales, L. T.; Birch, G. F.; Mar. Pollut. Bull. 2003, 46,719 .

3. Watermann, B. T.; Daehene, B.; Sievers, S.; Dannenberg, R.; Overbeke, J. C.; Klijnstra, J. W.; Heemken, O.; Chemosphere 2005, 60, 1530.

4. Singh, N.; Turner, A.; Environ. Pollut. 2009, 157, 371.

5. Boxall, A. B. A.; Comber, S. D.; Conrad, A. U.; Howeroft, J.; Zaman, N.; Mar. Pollut. Bull. 2000, 40, 898.

6. Warnken, J.; Dunn, R. J. K.; Teasdale, P. R.; Mar. Pollut. Bull. 2004, 49, 833. 
7. IMO.; International Conference on the Control of Harmful Anti-Fouling Systems on Ships. IMO Headquarters, London, UK, 2001. (also see: http://www.imo.org/)

8. Yebra, D. M.; Kiil, S.; Johansen, K. D.; Prog. Org. Coat. 2004, 50, 75.

9. Sunda, W. G.; Biological Oceanography 1989, 6, 411.

10. Vangronsveld, J.; Cunnihgham, S. D.; Metal Contaminated Soils: In Situ Inactivation and Phytoremediation. Springer Verlag: Berlin, 1989.

11. Leeuwen, H. P. V.; Town, R. M.; Buffle, J.; Cleven, R. F. M. J.; Davison, W.; Puy, J; Willem, H.; Riemsdijk, V.; Sigg, L.; Environ. Sci. Technol. $\mathbf{2 0 0 5}, 22,8545$.

12. Wallner-Kersanach, M.; Andrade, C. F. F; Milani, M. R.; Niencheski, L. F. H.; J. Braz. Chem. Soc. 2009, 20, 333.

13. Hong, Y. S.; Kinney, K. A.; Reible, D. D.; Environ. Toxicol. Chem. 2011, 30, 1775.

14. Tonietto, A. E.; Grassi, M. T.; Quim. Nova 2012, 35,170.

15. Beltrame, M. O.; De Marco, S. G.; Marcovecchio, J. E.; Estuarine, Coastal and Shelf Science 2009, 85, 45.

16. Montero, N.; Belzunce-Segarra, M. J.; Gonzales, J.-L.; Larreta, J.; Franco, J.; Mar. Pollut. Bull. 2012, 64, 31.

17. Turner, A.; Fitzer, S.; Glegg, G. A.; Environ. Pollut. 2008, 151, 176.

18. Parks, R.; Donnier-Marechal, M.; Frickers, P. E.; Turner, A.; Readman, J. W.; Mar. Pollut. Bull. 2010, 60, 1226.

19. Dunn, R. J. K.; Teasdale, P. R.; Warnken, J.; Jordan, M. A.; Arthur, J. M.; Environ. Pollut. 2007, 148, 213.

20. Zhang, H.; Davison, W.; Anal. Chem. 1995, 67, 3391.

21. Niencheski, L. F.; Windom, H. L.; Smith, R.; Mar. Pollut. Bull. 1994, $28,96$.

22. Windom, H. L.; Niencheski, L. F.; Smith, J. R. G.; Estuarine, Coastal and Shelf Science 1999, 48,113.

23. Niencheski, L. F.; Baumgarten, M. G. Z.; Aquat. Ecosyst. Health Manage. 2000, 4, 515 .

24. CONAMA - Conselho Nacional do Meio Ambiente, 2005. Resolução CONAMA 357. Brasília, DF.

25. Li, W.; Zhao, H.; Teasdale, P. R.; John, R.; Wang, F.; Anal. Chim. Acta. 2005, 533, 193.

26. Zhang, H.; Davison, W.; Practical guide for making diffusive gels and chelex gel. Skelmorlie, Quernmore, Lancaster LA2 0QJ, UK: DGT Research Ltda, 2004.

27. Niencheski, L. F.; Baumgarten, M. A.; In Subtropical Convergence Environments; Seeliger, U.; Odebrecht, C.; Castello, J. P., eds.; Springer: Berlin, 1996, p. 20.
28. Sutherland, R. A.; Appl. Geochem. 2002, 17, 353.

29. Möller, O. O. Jr.; Lorenzetti, J. A.; Stech, J. L.; Mata, M. M.; Cont. Shelf Res. 1996, 16, 335.

30. Garcia, C. A. E.; In Os Ecossistemas Costeiro e Marinho do Extremo Sul do Brasil; Seeliger, U.; Odebrecht, C.; Castello, J. P., eds.; Editora Ecoscientia: Rio Grande, 1998, p. 18.

31. Furlan, F.; Unpublished data.

32. DGT Research 2004. DGT for measurements in Waters, soils and sediment. http://dgtresearch.com/dgtreaserch.pdf, accessed in July 2010.

33. Strickland, J. D. H.; Parsons, T. R.; A pratical handbook of seawater analysis, $2^{\text {nd }}$ ed., Fisheries Research Board of Canada: Ottawa, 1972, pp. 311 .

34. Kremling, K.; Tokos, J. J. S.; Brügmann, L.; Hansen, H.-P.; Mar. Pollut. Bull. 1996, 34, 112.

35. Spyres, G.; Nimmo, M.; Worsfold, P. J.; Achterberg, E. P.; Miller, A. E. J.; TrAC, Trends Anal. Chem. 2000, 19, 498.

36. Ehrhardt, M.; Koeve, W.; In Methods of seawater analysis; Grasshoff, K. M.; Kremling, K., eds; Wiley-VCH: Weinhein, 1999, p. 437.

37. Harris, D. C.; Quantitative Chemical Analysis, $7^{\text {th }}$ ed., W. H. Freeman and Company: New York, 2007.

38. Zar, J. H.; Biostatistical Analysis, $5^{\text {th }}$ ed., Pearson Prentice Hall: New Jersey, 2010.

39. http://www.praticagemriogrande.com.br; accessed in July, October of 2010 and January of 2011.

40. Goñi, M. A.; Teixeira, M. J.; Perkey, D. W.; Estuarine, Coastal and Shelf Science 2003, 57, 1023.

41. Chakraborty, P.; Chakrabarti, L. C.; Anal. Chim. Acta 2006, 571, 260.

42. Turner, A.; Mar. Chem. 1996, 54, 27.

43. Santos, C. S.; Personal Communication.

44. Chiffoleau, J. F.; Cossa, D.; Auger, D.; Truquet, I.; Mar. Chem. 1994, 47,145 .

45. Sokolowski, A.; Wolowicz, M.; Hummel, H.; Mar. Pollut. Bull. 2001, 42, 967.

46. Munksgaard, N.; Parry, D. L.; J. Environ. Monit. 2003, 5, 145.

47. Schiff, K.; Brown, J.; Diehl, D.; Greenstein, D.; Mar. Pollut. Bull. 2007, $54,322$.

48. Biggs, T. W.; D’Anna, H.; Mar. Pollut. Bull 2012, 64, 627.

49. Costa, L. D. F; Wallner-Kersanach, M.; Environ. Monit. Assess. 2013, 185,6767 .

50. Turner, A.; Millward, G. E.; Estuarine, Coastal and Shelf Science 1993, 39,45 . 